\title{
Optimalisasi Penggunaan Alat Perlindungan Diri (APD) pada Masyarakat dalam Rangka Mencegah Penularan Virus COVID-19
}

\author{
Ni Made Nopita Wati ${ }^{*}$, Ni Kadek Yuni Lestari ${ }^{2,}$ Desak Made Ari Dwi Jayanti ${ }^{3,}$ \\ Nyoman Sudarma 4 \\ 1,2,3,4 STIKes Wira Medika Bali \\ *Email: ners.pita@gmail.com
}

\begin{abstract}
Background: COVID-19 is a pandemic that is being faced by all people in the world. COVID-19 transmission can be prevented by optimizing the use of PPE (Personal Proctection Equipment) such as masks. But there are still many people who do not know, understand and have the awareness to use them. Purpose of this study is to optimize using personal proctection equipment in community. Methods: Community service activities are carried aout throught health education with lecture methods, discussions and simulations of how to use PPE (Personal Proctection Equipment) such as masks. Results: The results of community service activities carried out have a positive impact and the community responds by implementing it in their daily lives. People ate starting to realize how important it is to use personal proctection during their daily activities which will have an impact on their health and safety during the COVID-19 pandemic. Conclusions: The implementation of community service activities can optimize the use of PPE to prevent COVID-19 transmission to the community and it is hoped that such activities can be carried out continuously so that COVID-19 transmission does not occur in the community.
\end{abstract}

Keywords: community, COVID-19, PPE

\section{PENDAHULUAN}

Pandemi corona virus 2019-2020 atau dikenal sebagai pandemi COVID-19 adalah peristiwa menyebarnya penyakit korona virus 2019 di seluruh dunia. Penyakit ini disebabkan oleh korona virus jenis baru yang diberi nama SARS-CoV-2 (Gorbalenya, 2020). Wabah COVID-19 pertama kali dideteksi di Kota Wuhan, Provinsi Hubei, Tiongkok pada bulan Desember 2019, dan ditetapkan sebagai pandemi oleh Organisasi Kesehatan Dunia (WHO) pada 11 Maret 2020 (WHO, 2020a). Hingga 28 Maret, lebih dari 620.000 kasus COVID-19 telah dilaporkan di lebih dari 190 negara dan teritori, mengakibatkan lebih dari 28.800 kematian dan 137.000 kesembuhan (Johns Hopkins University., 2020).

Virus SARS-CoV-2 diduga menyebar di antara orang-orang terutama melalui percikan pernapasan (droplet) yang dihasilkan selama batuk (US Centers for Disease Control and Prevention, 2019). Percikan ini juga dapat dihasilkan dari bersin dan pernapasan normal. Selain itu, virus dapat menyebar akibat menyentuh permukaan benda yang terkontaminasi dan kemudian menyentuh wajah seseorang. Penyakit COVID-19 paling menular saat orang yang menderitanya memiliki gejala, meskipun penyebaran mungkin saja terjadi sebelum gejala muncul (Rothan, H. A.; Byrareddy, 2020).

Periode waktu antara paparan virus dan munculnya gejala biasanya sekitar lima hari, tetapi dapat berkisar dari dua hingga empat belas hari. Gejala umum di antaranya demam, batuk, dan sesak napas. Komplikasi dapat berupa pneumonia dan sindrom gangguan pernafasan akut. Tidak ada vaksin atau pengobatan antivirus 
khusus untuk penyakit ini. Pengobatan primer yang diberikan berupa terapi simtomatik dan suportif. Langkah-langkah pencegahan yang direkomendasikan di antaranya mencuci tangan, menutup mulut saat batuk, menjaga jarak dari orang lain, serta pemantauan dan isolasi diri untuk orang yang mencurigai bahwa mereka terinfeksi, hanya saja belum semua masyarakat mentaati hal ini (Rothan, H. A.; Byrareddy, 2020).

Pandemi corona virus di Indonesia diawali dengan temuan penderita penyakit corona virus 2019 (Covid-19) pada 2 Maret 2020. Hingga 7 April 2020, telah terkonfirmasi 2.491 kasus positif COVID-19, dengan 209 kasus di antaranya meninggal dan 192 kasus sembuh. Kasus dinyatakan tersebar di 32 provinsi dari total 34 provinsi di Indonesia. Dua provinsi yang belum melaporkan kasus terkonfirmasi yaitu Gorontalo dan Nusa Tenggara Timur (Marchio, 2020). Para ahli kesehatan khawatir bahwa Indonesia gagal mengidentifikasi penularan virus. Marc Lipsitch, profesor epidemiologi di Universitas Harvard menganalisis lalu lintas pesawat udara dari Tiongkok dan menyimpulkan bahwa Indonesia mungkin telah memiliki kasus yang terlewatkan (Mc Veigh, Karen; Graham-Harrison, 2020). Pada 22 Maret, sebuah penelitian menyatakan bahwa jumlah infeksi resmi mungkin hanya merefleksikan 2\% dari jumlah infeksi COVID-19 sesungguhnya di Indonesia (Da Costa, 2020). Sejak saat ini mulailah bertambah kasus di Indonesia dengan angka kematian yang cukup drastis termasuk wilayah Bali. Adapun berbagai dampak yang ditimbulkan dari COVID-19 dari ekonomi, pendapatan masyarakat dan pariwisata.

Upaya yang dapat digunakan untuk memutus penularan COVID-19 salah satunya adalah dengan menggunakan APD (Alat Pelindung Diri). Berdasarkan Permenaker nomor 8 tahun 2010, alat pelindung diri adalah suatu alat yang mempunyai kemampuan untuk melindungi seseorang yang fungsinya mengisolasi sebagian atau seluruh tubuh dari potensi bahaya. Fungsi dan jenis alat pelindung diri (APD) terdapat beraneka macam. Alat Pelindung Diri (APD) yang berfungsi untuk melindungi anggota tubuh dan ada pula yang berfungsi sebagai alat dalam gawat darurat. Salah satu APD yang wajib digunakan dalam mengurangi penyebaran virus COVID-19 ini adalah berupa masker, namun sampai saat ini masih banyak masyarakat yang tidak menggunakan masker saat keluar rumah dimana hal ini terjadi karena kurangnya pengetahuan dan kesadaran masyarakat. Tujuan dari pengabdian masyarakat ini adalah untuk meningkatan pengetahuan dan kesadaran masyarakat dengan cara mengoptimalkan penggunaan APD (Alat Perlindungan Diri) di masyarakat untuk mencegah penyebaran virus COVID-19.

\section{TINJAUAN PUSTAKA}

\subsection{Penyuluhan}

Penyuluhan kesehatan adalah penambahan pengetahuan dan kemampuan seseorang melalui teknik praktek belajar atau instruksi dengan tujuan mengubah atau mempengaruhi perilaku manusia secara individu, kelompok maupun masyarakat untuk dapat lebih mandiri dalam mencapai tujuan hidup sehat. Sasaran penyuluhan kesehatan mencakup individu, keluarga, kelompok dan masyarakat. Penyuluhan kesehatan pada individu dapat dilakukan di rumah sakit, klinik, puskesmas, 
posyandu, keluarga binaan dan masyarakat binaan. Penyuluhan kesehatan pada keluarga diutamakan pada keluarga risiko tinggi, seperti keluarga yang menderita penyakit menular, keluarga dengan sosial ekonomi rendah, keluarga dengan keadaan gizi yang buruk, keluarga dengan sanitasi lingkungan yang buruk dan sebagainya. Penyuluhan kesehatan pada sasaran masyarakat dapat dilakukan pada masyarakat binaan puskesmas, masyarakat nelayan, masyarakat pedesaan, masyarakat yang terkena wabah dan lain-lain.

\subsection{Materi atau Pesan}

Materi atau pesan yang disampaikan kepada sasaran hendaknya disesuaikan dengan kebutuhan kesehatan dari individu, keluarga, kelompok dan masyarakat, sehingga materi yang disampaikan dapat dirasakan langsung manfaatnya. Materi yang disampaikan sebaiknya menggunakan bahasa yang mudah dimengerti, tidak terlalu sulit untuk dimengerti oleh sasaran, dalam penyampaian materi sebaiknya menggunakan metode dan media untuk mempermudah pemahaman dan untuk menarik perhatian sasaran.

\subsection{Faktor-Faktor yang Mempengaruhi dalam Penyuluhan}

Keberhasilan suatu penyuluhan kesehatan dapat dipengaruhi oleh faktor penyuluh, sasaran dan proses penyuluhan.

a. Faktor penyuluh, misalnya kurang persiapan, kurang menguasai materi yang akan dijelaskan, penampilan kurang meyakinkan sasaran, bahasa yang digunakan kurang dapat dimengerti oleh sasaran, suara terlalu kecil dan kurang dapat didengar serta penyampaian materi penyuluhan terlalu monoton sehingga membosankan.

b. Faktor sasaran, misalnya tingkat pendidikan terlalu rendah sehingga sulit menerima pesan yang disampaikan, tingkat sosial ekonomi terlalu rendah sehingga tidak begitu memperhatikan pesan-pesan yang disampaikan karena lebih memikirkan kebutuhan yang lebih mendesak, kepercayaan dan adat kebiasaan yang telah tertanam sehingga sulit untuk mengubahnya serta kondisi lingkungan tempat tinggal sasaran yang tidak mungkin terjadi perubahan perilaku.

c. Faktor proses dalam penyuluhan, misalnya waktu penyuluhan tidak sesuai dengan waktu yang diinginkan sasaran, tempat penyuluhan dekat dengan keramaian sehingga mengganggu proses penyuluhan yang dilakukan, jumlah sasaran penyuluhan yang terlalu banyak, alat peraga yang kurang, metode yang digunakan kurang tepat sehingga membosankan sasaran, serta bahasa yang digunakan kurang dimengerti oleh sasaran.

\subsection{COVID-19}

Virus COVID-19 disebabkan oleh filogenetik dan taksonomi, virus corona baru awalnya disimbolkan 2019-nCoV oleh WHO, dengan huruf $n$ yang berarti novel atau baru, dan CoV yang berarti coronavirus atau virus corona (WHO, 2020). Virus ini tergolong dalam ordo Nidovirales, keluarga Coronaviridae, dan genus Betacoronavirus (Beta-CoV). Genus betacoronavirus terdiri atas empat garis 
keturunan (subgenus), di mana 2019-nCoV bersama dengan SARS-CoV digolongkan dalam garis keturunan B (subgenus Sarbecovirus) (Antonio,2019). Virus 2019-nCoV merupakan spesies ketujuh dalam keluarga Coronaviridae yang mampu menginfeksi manusia, selain 229E, NL63, OC43, HKU1, MERS-CoV, dan SARS-CoV. Pada 11 Februari 2020, Komite Internasional Taksonomi Virus (ICTV) memberi nama virus ini koronavirus sindrom pernapasan akut berat 2 (Severe acute respiratory syndrome coronavirus 2, disingkat SARS-CoV-2) yang merupakan galur dalam spesies SARSCoV (Zhou et al, 2020).

Untuk mencegah infeksi, WHO merekomendasikan mencuci tangan secara teratur, menutupi mulut dan hidung ketika batuk dan bersin, hindari kontak dekat dengan siapa pun yang menunjukkan gejala penyakit pernapasan (seperti batuk dan bersin. Meskipun tidak ada perawatan khusus untuk virus corona manusia pada umumnya, Pusat Pengendalian dan Pencegahan Penyakit AS menyarankan bahwa warga yang terinfeksi virus ini dapat meredakan gejalanya dengan minum obat flu biasa, minum cairan, dan istirahat. Beberapa negara mengharuskan warganya untuk melaporkan gejala mirip flu ke dokter mereka, terutama jika mereka pernah mengunjungi daratan Tiongkok (Colangelo, Anthony; Wicks, 2020).

\subsection{APD (Alat Pelindung Diri)}

APD adalah alat yang digunakan untuk melindungi diri dan mencegah infeksi nosokomial. Tujuan penggunaan APD untuk melindungi kulit dari pajanan semua cairan tubuh dari kontak langsung dengan orang lain. Adapun APD yang dapat digunakan oleh masayarakat untuk mencegah penularan COVID-19 adalah :

a. Masker

Masker bagian dari alat pelindung wajah khususnya untuk melindungi membran mukosa pada mulut dan hidung ketika berinteraksi dengan orang lain. Masker dianjurkan untuk selalu digunakan ketika keluar rumah. Masker dapat melindungi kita terhadap transmisi infeksi melalui udara. Secara umum masker dibagi menjadi dua jenis yaitu masker standart dan masker khusus yang dibuat untuk menyaring patikel-partikel atau mikroorganisme kecil.

b. Face shield

Face shield adalah pelindung wajah yang dapat melindungi mata dan wajah kita dari percikan cairan ataupun droplet. Face shield ini terbuat dari plastic bening yang dapat memberikan visibilitas yang baik bagi pemakainya. Face shield ini tahan terhadap uap air dan dapat disesuaikan untuk melekat dengan kuat di sekeliling kepala dan pas pada dahi.

\section{DESAIN PENELITIAN}

Kegiatan pengabdian masyarakat ini dilakukan melalui beberapa tahapan kegiatan yaitu :

a. Survey awal

Survey dilakukan terhadap aktivitas masyarakat. Kegiatan ini dilakukan pada tanggal 21 April 2020. Metode yang dipakai adalah metode observasi dan wawancara dengan sasaran kegiatan adalah masyarakat. 
b. Pelaksanaan kegiatan

Kegiatan ini dilakukan pada tanggal 28 April 2020. Pelaksanaan kegiatan pengabdian masyarakat ini diwujudkan dalam kegiatan sosialisasi terkait pentingnya penggunaan APD untuk mencegah penularan COVID-19 di masyarakat. Kegiatan ini dilakukan dengan memberikan penyuluhan kesehatan melalui ceramah, simulasi penggunaan dan pembagian APD secara gratis. Penyuluhan di berikan oleh dosen STIKes Wira Medika Bali dengan jumlah peserta yang hadir sebanyak 20 orang.

c. Evaluasi kegiatan

Evaluasi kegiatan dilakukan pada akhir pelaksanaan kegiatan dengan metode observasi dan wawancara terkait dengan pengimplementasian masyarakat dalam menggunakan APD yang diberikan.

\section{HASIL PENELITIAN}

Sebagaimana permasalahan yang ada, maka diperlukan solusi untuk menyelesaikannya yaitu dengan melakukan sosialisasi tentang pentingnya optimalisasi penggunaan APD di masyarakat untuk mencegah penularan COVID-19. Pelaksanaan kegiatan ini dilakukan melalui beberapa tahapan kegiatan yaitu :

a. Survey awal

Survey awal ini dilakukan pada awal bulan Maret 2020 dengan metode observasi dan wawancara terhadap aktivitas masyarakat. Dari hasil pengamatan diperoleh kesimpulan bahwa dalam melakukan aktivitas sehari-harinya di luar rumah sebagian besar masyarakat belum memiliki pengetahuan dan kesadaran menggunakan APD seperti masker. Beberapa masyarakat mengatakan alasan tidak menggunakan masker karena mereka tidak mengetahui bahwa menggunakan APD seperti masker dapat mencegah penularan virus COVID-19. Masyarakat lainya mengatakan tidak menggunakan APD seperti masker karena tidak memiliki masker. Masyarakat juga mengatakan kesulitan dalam membeli masker. Disamping itu masyarakat juga belum memahami dengan baik tentang pencegahan penularan virus COVID-19.

b. Pelaksanaan kegiatan

Kegiatan pengabdian masyarakat ini di realisasikan pada tanggal 28 April 2020. Pelaksanaan kegiatan pengabdian masyarakat ini diwujudkan dalam kegiatan penyuluhan kesehatan dengan metode ceramah tentang COVID-19 terutama pencegahan penularan virus COVID-19 ini di masyarakat. Penyuluah kesehatan ini juga dilanjutkan dengan interaksi tanya jawab serta simulasi cara menggunakan APD, seperti masker yang diperagakan langsung oleh tim pengabdian masyarakat. Simulasi dilakukan dengan menjelaskan tata cara penggunaan alat perlindungan diri bagi masayarakat saat akan melakukan aktivitas di luar rumah. Masyarakat yang datang juga dibagikan APD berupa masker secara gratis agar mereka dapat langsung mempraktekkan dan menggunakan masker sebagai salah satu alat perlindungan diri untuk mencegah penularan COVID-19 di masyarakat. 


\section{c. Evaluasi kegiatan}

Evaluasi dilakukan 2 minggu setelah kegiatan berlangsung dengan metode observasi dan wawancara terhadap kesadaran masyarakat saat akan melakukan aktivitas di luar rumah. Dari hasil pengamatan terhadap aktivitas masyarakat di luar rumah terlihat bahwa sebagain besar masyarakat sudah mulai menggunakan APD yaitu masker saat bepergian atau melakukan aktivitas di luar rumah. Hal ini tentu dapat menjelaskan bahwa hasil kegiatan pengabdian masyarakat yang dilakukan berdampak positif dan masyarakat meresponnya dengan mengimplementasikannya dalam kesehariannya. Masyarakat mulai menyadari betapa pentingnya menggunakan alat perlindungan diri selama melakukan aktivitas sehari-hari yang akan berdampak pada kesehatan dan keselamatan mereka di saat pandemi COVID-19 ini.

\section{PEMBAHASAN}

COVID-19 merupakan pandemi yang sedang di hadapi oleh seluruh masyarakat di dunia. COVID-19 ini di dapat dicegah penularannya dengan menerapkan pola hidup bersih dan sehat karena itu penularan COVID-19 ini sangat tergantung kebiasaan masyarakat dalam menerapkan pola hidup bersih dan sehat dalam kehidupan sehari-hari. COVID-19 dapat dicegah asalkan masyarakat mau patuh melaksanakan pola hidup bersih dan sehat misalnya melalui mencuci tangan. Pencegahan penularan COVID-19 dapat dilakukan melalui kegiatan penyuluhan.

Penyuluhan kesehatan dilakukan karena kurangnya pengetahuan akan mempengaruhi kondisi masyarakat dan dapat meningkatkan kesadaran masyarakat untuk senantiasa menerapkan pola hidup bersih dan sehat. Penyuluhan kesehatan juga dilakukan untuk menekan angka kejadian COVID-19. Penyuluhan ini dilakukan dengan menggunakan media LCD dan pemaparan materi menggunakan powerpoint serta pemutaran video. Masyarakat terlihat sangat antusias menyimak dan memperhatikan materi yang dipaparkan oleh penyuluh. Ini terlihat dari hasil evaluasi subjektif dan objektif setelah diberikan penyuluhan, sebagian besar masyarakat mampu menyimpulkan kembali materi yang telah dipaparkan. Hal ini sejalan dengan hasil pengabdian masyarakat yang dilakukan oleh (Hastuti, S, Aisah, Antika, \& D, 2020), yang menyatakan bahwa hasil kegiatan penyuluhan menunjukkan antusiasme, peningkatan pengetahuan, dan kemauan tinggi pasien dan keluarga dalam melaksanakan cuci tangan sesuai yang disuluhkan. Kegiatan lain yang dilakukan dalam pengabdian masyarakat ini adalah demosntrasi cara mencuci tangan, etika batuk dan penggunaan masker dimana kegiatan ini merupakan salah satu upaya pencegahan penularan COVID-19 di masyarakat. Disamping itu juga dilakukan kegiatan pembagian masker secara gratis.

APD yang diberikan oleh tim pengabmas pada kegiatan ini berupa masker dan face shield dimana APD sendiri merupakan alat yang digunakan untuk melindungi diri dan mencegah infeksi nosokomial. Tujuan penggunaan APD untuk melindungi kulit dari pajanan semua cairan tubuh dari kontak langsung dengan orang lain. Masker bagian dari alat pelindung wajah khususnya untuk melindungi membran mukosa pada mulut dan hidung perawat ketika berinteraksi dengan orang lain. 
Masker dianjurkan untuk selalu digunakan ketika keluar rumah. Masker dapat melindungi kita terhadap transmisi infeksi melalui udara. Secara umum masker dibagi menjadi dua jenis yaitu masker standart dan masker khusus yang dibuat untuk menyaring patikel-partikel atau mikroorganisme kecil.

\section{KESIMPULAN DAN SARAN}

\subsection{Kesimpulan}

Pelaksanaan kegiatan PKM yang terdiri dari penyuluhan kesehatan dengan metode ceramh, diskusi serta simulasi dan pemberian bantuan berupa masker dapat meningkatkan pengetahuan, pemahaman, kesadaran serta mengoptimalkan pelaksanaan APD untuk mencegah penularan COVID-19 pada masyarakat dimana masyarakat yang hadir sangat aktif dan antusias terhadap kegiatan yang sudah dilakukan.

\subsection{Saran}

Program pengabdian ini diharapkan dapat dilaksanakan secara berkelanjutan agar tidak terjadi penularan COVID-19 di masyarakat. Diharapkan kepada tokoh masyarakat, serta perangkat desa agar lebih aktif dalam melakukan penyuluhan serupa dengan melibatkan pihak-pihak terkait untuk mencegah serta mengurangi resiko penularan penyakit COVID-19 di masyarakat.

\section{UCAPAN TERIMA KASIH}

Penghargaan setinggi-tingginya untuk STIKes Wira Medika Bali yang telah mensupport penuh kegiatan ini sehingga kegiatan pengabdian masyarakat ini bisa terlaksana dengan baik.

\section{DAFTAR RUJUKAN}

Colangelo, Anthony; Wicks, K. (2020). "Matildas"' Olympic qualifiers switched to Sydney after virus fears"."

Da Costa, A. B. (2020). "Indonesia says lack of COVID-19 cases a blessing from God."

Gorbalenya, A. E. (2020). "Severe acute respiratory syndrome-related coronavirus The species and its viruses, a statement of the Coronavirus Study Group". https://doi.org/10.1101/2020.02.07.937862

Hastuti, P., S, N. A., Aisah, N. N., Antika, L., \& D, O. S. (2020). Jurnal Pengabdian Kesehatan STIKES Cendekia Utama Kudus. 3(1), 91-99

Johns Hopkins University. (2020). Coronavirus COVID-19 Global Cases. Retrieved from Diakses tanggal 20 March 2020

Marchio, I. G. (2020). “BREAKING - Jokowi announces Indonesia's first two confirmed COVID-19 cases." 
Mc Veigh, Karen; Graham-Harrison, E. (2020). "Academic stands by research querying Indonesia's claim to be coronavirus-free". The Guardian (Dalam Bahasa Inggris). ISSN 0261-3077.

Rothan, H. A.; Byrareddy, S. N. (2020). "The epidemiology and pathogenesis of coronavirus disease (COVID-19) outbreak." Journal of Autoimmunity, 102433. https://doi.org/10.1016/j.jaut.2020.102433.

US Centers for Disease Control and Prevention. (2019). Symptoms of Novel Coronavirus (2019-nCoV).

WHO. (2020a). General's opening remarks at the media briefing on COVID-19 - 11 March 2020". Retrieved from www.who.int (dalam bahasa Inggris).

WHO. (2020b). Novel Coronavirus (2019-nCoV) Situation Report.

Zhou, Peng; Yang, Xing-Lou; Wang, Xian-Guang; Hu, Ben; Zhang, Lei; Zhang, Wei; Si, H.-R. bioRxi. (2020). Discovery of a novel coronavirus associated with the recent pneumonia outbreak in humans and its potential bat origin. https://doi.org/10.1101/2020.01.22.914952 